\title{
Authors' reply: Management of patients with Ebola virus disease in Europe: high-level isolation units should have a key role
}

M D de Jong (m.d.dejong@amc.uva.nl)1, M Koopmans ${ }^{2}$, H Goossens ${ }^{3}$, on behalf of the authors of the original article ${ }^{4}$

1. Department of Medical Microbiology, Academic Medical Center, Amsterdam, the Netherlands

2. Department of Viroscience, Erasmus Medical Center, Rotterdam, the Netherlands

3. Department of Clinical Pathology, University Hospital Antwerp, Antwerp, Belgium

4. http://www.eurosurveillance.org/ViewArticle.aspx?Articleld=20980

Citation style for this article:

de Jong MD, Koopmans M, Goossens H, on behalf of the authors of the original article. Authors' reply: Management of patients with Ebola virus disease in Europe: high-level isolation units should have a key role. Euro Surveill. 2014;19(50):pii=20990. Available online: http://www.eurosurveillance.org/ViewArticle. aspx?Articleld=20990

Article submitted on 16 December 2014 / published on 18 December 2014

Ippolito and colleagues suggest a key role of high-level isolation units (HLIUs) for patient management and containment of Ebola virus disease (EVD) in Europe [1]. In principle, we do agree with this notion, particularly in relation to repatriated or evacuated patients with confirmed EVD. However, realities are (i) that patients with (suspected) EVD who are in need of care may present at any hospital anywhere in Europe, and (ii) that the number and geographic distribution of HLIUs are limited which pose difficulties particularly in the unlikely event of multiple introductions or spread of EVD (or other highly infectious diseases) in Europe. For these reasons, preparedness for admission of suspected patients or procedures for transfer of such patients to other hospitals are essential, and this is what we sought to assess in our survey [2].

As noted by Ippolito et al., practical exercises of preparedness are important and were performed in only $\mathbf{2 8 \%}$ of hospitals overall at the time of the survey. However, somewhat reassuringly, it should be noted that this percentage was substantially higher in hospitals that would admit suspected patients (46\%). Also, it should be noted that this survey was initiated less than three weeks after the World Health Organization's Public Health Emergency of International Concern (PHEIC) declaration [3], and that preparedness activities, including exercises, will likely have intensified since then.

In conclusion, efforts to identify and address gaps in preparedness of European hospitals are essential to assess and manage the risk of possible spread of EVD or the next emerging highly infectious disease in Europe. Notwithstanding their importance, reliance solely on HLIUs for containment of EVD or other highly infectious diseases may be unrealistic.
Conflict of interest

None declared.

Authors' contribution

MDdJ, MK and HG wrote the letter.

\section{References}

1. Ippolito G, Puro V, Brouqui P, Lauria FN, Fusco FM, on behalf of the EuroNHID Consortium. Letter to the editor: Management of patients with Ebola virus disease in Europe: high-level isolation units should have a key role. Euro Surveill. 2014;19(50):pii=20993. Available from: http://www. eurosurveillance.org/ViewArticle.aspx?Articleld=20993

2. de Jong MD, Reusken C, Horby P, Koopmans M, Bonten M, Chiche JD, et al. Preparedness for admission of patients with suspected Ebola virus disease in European hospitals: a survey, August-September 2014. Euro Surveill. 2014;19(48): pii=20980, Available from: http://www.eurosurveillance.org/ViewArticle. aspx?Articleld $=20980$

3. World Health Organization (WHO). Statement on the 1st meeting of the IHR Emergency Committee on the 2014 Ebola outbreak in West Africa. Geneva: WHO. 8 Aug 2014. Available from: http://www.who.int/mediacentre/news/ statements/2014/ebola-20140808/en/ 